\title{
The changing value of land in northern Kenya: the case of Lake Turkana Wind Power
}

\author{
Zoe Cormack and Abdikadir Kurewa
}

Lake Turkana Wind Power, situated on the eastern shores of Lake Turkana in northern Kenya, is currently the largest wind-power project in Africa and the biggest private investment in Kenyan history. While this project enjoys strong support from the Kenyan government, at the local level it has unfolded amid considerable controversy and has been accompanied by accusations of land-grabbing, corporate negligence and infringement of indigenous and customary land rights. This article examines the local effects of the Lake Turkana Wind Power's construction. It explores how the value of land has been transformed by the wind farm and the effects this has had on local social relationships, territoriality and connections to place. The largescale, rapid privatisation of land and infrastructure development has produced a variety of apparently contradictory effects; local people simultaneously seek to access 'benefits' from the project and experience new forms of exclusion. This is particularly clear in disputes over the distribution of employment and corporate social investment. A notable consequence has been increasingly exclusive claims to land and interpretations of local history -new values ascribed to the land have generated new feelings of entitlement and raised expectations of 'development'. These contestations reveal that the value of land is about more that the material resource itself. It rests on what other privileges can be accessed through claims to place and belonging.

Keywords: land; infrastructure; renewable energy; northern Kenya; frontier development

'Lake Turkana Wind Power' (LTWP) is currently the largest wind-power project in Africa and the biggest private investment in Kenyan history. It promises to transform energy production in Kenya by supplying up to $18 \%$ of the national grid with cheap, renewable energy. By doing so, this project is slated to provide a new model for low carbon emission development in Africa (Cookson et al. 2017). The wind farm is situated in a $607 \mathrm{Km}^{2}$ concession on the eastern shores of Lake Turkana, in Marsabit County, one of the poorest parts of Kenya. LTWP is by far the largest investment to have ever been constructed in this region and is part of a wave of infrastructure and power generation projects which aim to transform previously neglected northern Kenya from a pastoralist 'periphery' into a productive heartland. To this end, LTWP has been enshrined as a 'flagship' project in 'Vision 2030' - Kenya's national development plan. ${ }^{1}$ However, the construction of LTWP's facility has also been accompanied by accusations of land grabbing, infringement of indigenous and customary land rights and concerns over resettlement (Voller et al. 2016; Sena 2015). The construction of the wind farm, and the controversies it has raised, sit at the intersection of - and push us to think harder about - many classic and emerging themes in the study of land, identity and development in Africa. It strikingly illuminates issues of territoriality, the transformation of communally held land and the local realities of frontier infrastructure development.

This article is about the local effects of this project. It explores the impacts of LTWP on social relations, place and notions of territoriality in the project concession. We argue that 
the changing value of land is key to understanding what this project means 'on the ground'. In some respects, the construction of the wind farm has transformed the value and significance of land as its economic value has been recalibrated towards wind energy production. The almost surreal notion of turning wind into money looms large in the local imagination - 'if only we'd known the wind was worth something!' one local businessman joked. ${ }^{2}$ LTWP has also generated new opportunities - seen as 'benefits' of the project. These include employment with its building contractors, security operation and a corporate social responsibility (CSR) programme. However, this new corporate-economic value has not displaced existing values and associations placed on the land. Conversely, the project has reanimated a suite of historical and cultural attachments to land. Residents of the concession are increasingly invoking these connections to position themselves as legitimate beneficiaries of LTWP. Attempts to secure 'benefits' and be part of 'development' have created new forms of exclusion and raised questions over who is entitled to access wind-power resources. These debates are having profound effects on local social relationships, as different groups living in the project footprint have felt the need to protect their own interests by making increasingly exclusive claims to land.

Our findings are based on joint field research at the project site over two weeks in April and May 2016. Twenty-eight key informant interviews were carried out in Loiyangalani, South Horr, Sarima and Marsabit Town. Interviewees were selected because they held a diversity of views and relationships with the project. They included members of local community-based organisations, religious leaders, elders, business people, people who had attended community meetings with LTWP, people who had experienced resettlement by LTWP, unemployed youth, employees of LTWP, members of the local administration and Marsabit County government including complainants in a court case against LTWP. Further research was conducted in the Kenyan National Archives and we analysed official project documentation - including environmental and social impact assessments, relocation plans and indigenous people policy frameworks. This study was conducted in the context of a larger research project (involving Cormack), investigating how citizens are claiming cultural rights in Kenya. Kurewa is a heritage professional who was born and until recently worked in Loiyangalani. He has witnessed many of the LTWP developments first hand.

Our argument develops in three parts. We first explain the background to the project and its objectives in more detail. Our aim is to contextualise LTWP within the current regional precedent for largescale infrastructure development in historically marginalised pastoralist regions of north-eastern Africa as these investments develop alongside changing notions of land value and territoriality. In this context, we also highlight some aspects of LTWP's relationship with local people that have raised concern from international human rights bodies. Many of these issues are underpinned by profound power inequalities, which in turn impact on local interpretations of the project. Second, we turn in more detail to different perspectives on the land and how its value is differently constituted by various actors. The LTWP consortium has framed the Marsabit landscape as an investable terra nullius. This contrasts with the historic local significance ascribed to the same land by people living in the project concession. We illuminate a different view of the concession as a site of interaction between different groups of herders who made strategic use of natural resources and distance from government authorities. The third part turns to the effects changing values of land are having on social 
relations and notions of territoriality around the project. We examine different claims being made on the concession: who has a legitimate stake in the development 'benefits' from LTWP? Far from entering an empty space, the arrival of the project has reanimated conflicting local versions of history and belonging. Therefore, the new value of land is inseparable from the interpretations of the past, which now form the basis of claims to rights in land (Berry 2007, 64-65). These findings echo other research showing how the past remains 'active and affective' in configuring new relationships to land and among its inhabitants, even in the context of largescale transformation (Fontein 2016, 1). The experience in the LTWP concession also reveals how the value of land may be constituted not only around the material resource itself, but also around a spectrum of privileges and aspirations that people hope to access through a stake in land.

\section{Development, infrastructure and the value of land in northern Kenya.}

The setting for LTWP is Marsabit county in northern Kenya. During British colonial rule this area was part of the 'Northern Frontier District' (NFD); an arid and predominantly pastoralist region regarded as having low economic potential. It was principally imagined as a 'buffer zone' between Ethiopia and the agricultural heartland of Kenya. The British administration deemed it most economical to intervene as little as possible in the NFD; provided people stayed within their allotted 'tribal grazing area' and paid taxes they were left alone (Hogg 1987, 49). The north was regarded as a 'closed' district and largely excluded from outside influence. For these reasons, there was very sparse investment: little infrastructure and no schools were built (Carrier and Kochore 2014, 136). Lack of investment in security and the influx of small arms from neighbouring countries has entrenched some local conflicts and led to the region's reputation as a perennial 'bad-lands' (Mwangi 2006). Together, this created a legacy of inequality that continued long after Independence. In 2009, the Prime Minister could even state 'Kenya has been defined by the railway line. The rest of the country was neglected; the NFD was just an empty space on the map' (in Elmi and Birch 2013, 3).

In recent years, this image of northern Kenya as an 'empty space on the map' has begun to change. Regions of northern Kenya and southern Ethiopia, previously seen as having little to offer to national development, have become the subject of huge power and infrastructure projects and state-led development blueprints (Mosley and Watson 2016, 452). Northern Kenya is a key part of the government's Vision 2030, which aims to transform Kenya into a middle-income country by the year 2030 (GoK 2012). Power generation is central to Kenya's development plan and the current President Uhuru Kenyatta's administration has scaled up investment in renewable energy projects, primarily wind and geothermal (Sena 2015, 6). The discovery of oil in Turkana County (on the western side of Lake Turkana) and plans for a regional transport network and oil pipeline (called LAPSSET - the Lamu Port South Sudan and Ethiopia Transport Corridor) have fuelled speculations that the north is the future engine of Kenya's economic development.

The establishment of high-capital, transformative projects in regions of poverty and insecurity has also raised concerns about their potential to create social tensions and become catalysts for conflict (Browne 2015, 62-64; Menkhaus 2014, 35-37). Northern Kenya has not 
seen dramatic development-induced displacement on the scale of the Omo valley in Ethiopia (Buffavand 2016; Fratkin 2014; Human Rights Watch 2012). However, research on the impacts of oil exploration on the western side of the Lake Turkana has begun to expose the effects of extractive industry, privatisation and infrastructure on security (Johannes et al. 2015; Mkutu Agade 2015), governance (Mkutu Agade 2014), relationships with the state and citizenship (Enns and Bersaglio 2015), and pastoralist livelihoods (Opiyo et al. 2015; Enns and Bersaglio 2016). These studies all point to ways in which infrastructural development is altering social and political relationships between different actors on the ground.

Recent anthropological work on large infrastructure projects in northern Kenya has highlighted their contradictory effects, especially the degree to which a range of local actors may invest in the prospects of development and capitalist modernity alongside the profound anxiety that this infrastructure can produce (Elliott 2016; Kochore 2016). LTWP has many characteristics that provoke ambivalent reactions. The wind farm is infrastructure as a grand spectacle (Larkin 2013, 336) and resembles high modernist development projects of the past (Scott 1998; Mosley and Watson 2016, 456-457). Locally, LTWP also has the appearance of an 'enclave development': it is highly technologically sophisticated, isolated from the local context (the power generated will be piped directed to a processing plant in central Kenya) and it employs skilled foreign workers or workers from other parts of the country; it is also highly securitised (Ferguson 2005, 378). Yet the wind farm also has 'enchanting' effects; it has drawn together different - some almost utopian - aspirations for an innovative modern future for a long-marginalised part of Kenya (Harvey and Knox 2012). This is a central part of the company's own narrative, which stresses the benefits it will bring to the local population through connectivity and corporate social responsibility programmes. As observed in the growing wind industry in Mexico, LTWP is framed and legitimised through a 'communalist logic' of development in which the wind energy is supposed to benefit everyone by providing clean energy for national development and benefitting the local community (Howe 2011, 3). However, the fallacies of the 'communalist logic' of development are especially visible at the local level, where many people feel profoundly excluded from the benefits of LTWP. These contradictions are evident in the LTWP concession, where there is both 'buy in' and contestation of the future promoted by LTWP's corporate narrative. Some residents are 'enchanted' by its promises - at the same time they are experiencing new forms of exclusion resulting from the exercise of corporate power.

In this process, new configurations of territoriality and belonging are being negotiated. Land and territoriality, i.e. strategies to control land and its resources (Sack 1986, 20), have become critical issues. The LTWP consortium has leased (effectively privatizing) $607 \mathrm{~km}^{2}$ of land in a region where communal land use is the norm and an essential part of pastoralist livelihoods. This makes LTWP an extreme example of the wider trend towards privatisation and fragmentation of communal land in Eastern Africa (Galvin 2009). Studies of similar processes in Kenya (and more widely) have shown that changing tenure arrangements affect not only subsistence but a range of social relations that are traditionally mediated through land (Shipton 2009). The implications of this are complex and mean that land issues play several, interconnected roles in anxieties and disputes over the project. Despite common threads, the LTWP case is different from many existing case studies, which have focused on the acquisition of individual title for land. In this case, the LTWP consortium holds a lease on the land and 
local people are dealing with the effects of corporate exclusion. Several recent analyses of territoriality in pastoralist regions of the Horn of Africa help to understand the dynamics around LTWP. These works have mapped how these processes of territorialisation are driven by a complex mixture of external and internal factors such as state formation or commoditization (Cormack 2016a; Hoehne 2016; Korf et al 2015). Transformations in the LTWP concession show how the external factor of a largescale infrastructure development has met with local agendas.

\section{The Lake Turkana Wind Power Project}

According to LTWP's origin story, in the early 1990s, Willem Dolleman - a Dutchman living in Kenya - was in the habit of making annual trips to the eastern shores of Lake Turkana to go fishing. There were not enough tourist lodges in this remote region, so Dollemen used to pitch a tent close to the best fishing spots. Frequently, his tent would be blown away in the night because of the extraordinary winds, and Dollemen would end up sleeping in his car. Dollemen told a fellow Dutchman in Kenya, Carlo van Wageningen that these unique conditions would make the ideal location for a wind farm. In the early 2000s, the price of oil began to rise and the possibility of a wind farm on Lake Turkana became commercially viable (Mutiga and Smith 2015). The LTWP consortium was founded in 2006 and given exclusive rights to study the wind potential around Lake Turkana (LTWP 2011, 1).

A decade later, LTWP has become the biggest public-private investment in Kenyan history and the largest wind farm in Africa. The consortium is now made up of four private companies - Aldwych International (a British company which is the largest shareholder), KP\&P Africa (a Dutch firm), Vestas Wind Systems (a Danish wind turbine company) and Sandpiper - and Norwegian, Finish and Danish governmental development funds. The total cost of the project is $\$ 865$ million, which was secured in 2014 (Cookson et al. 2017, 3). The African Development Bank has taken the lead role in financing the project. At an earlier stage, the World Bank were partly financing the wind farm, but they pulled out in 2012 due to concerns that Kenya did not have the capacity to consume all the wind-power that would be generated (Dodd 2012). LTWP has also attracted wider attention: notably Google have agreed to buy out $\$ 40$ million dollars of shares from Vestas once the turbines have been constructed. This is Google’s largest investment in Africa to date (Cusick 2016).

The public partnership comes through a power purchase agreement with Kenya Power, committing the Kenyan government to buy LTWP generated wind-power for twenty years (Anon 2014). As part of this deal, Ketraco (a government subsidiary) will construct a $428 \mathrm{~km}$ transmission line to transport the energy from Marsabit to a substation at Suswa in the Rift Valley (Muthoka 2011, 1). Work on the transmission line has been delayed. The Kenyan government agreed to buy out the contractors to ensure the scheduled completion of the line (Anon 2017b) However, at the time of writing, continued delays on the transmission line have resulted in the LTWP charging the Kenyan Government 5.7 billion Kenyan shilling (approximately $£ 41$ million $^{3}$ ) in lost assets for failing to connect the power to the national grid (Kamau 2017). The delay also limits the funds available for CSR investment because these are calculated as a percentage of energy sales (Rottmann 2017). 
To construct its facility, LTWP leased 150,000 acres of land $\left(607 \mathrm{~km}^{2}\right)$ in Loiyangalani ward of Laisamis constituency of Marsabit County. The concession extends to the border between Marsabit and Samburu Counties and over a valley that provides access to Lake Turkana to the south of Mount Kulal Biosphere Reserve (a UNESCO recognised site). It encompasses grazing land and seasonal water points at a place called Sarima (where the wind turbines have been installed). This is an area which Samburu, Turkana and Rendille pastoralists have historically jointly utilised. ${ }^{4}$ The wind farm itself is situated in a sub-tropical wind jet stream which passes between Mount Kulal and Mount Nyiru in a valley that leads down to the south-eastern corner of Lake Turkana (LOG Associates 2012c, vi). Its footprint is 40,000 acres; it consists of 365 turbines and various installations needed to process the wind energy. The remaining 110,000 acres in the concession have been designated as a 'buffer zone' to secure the wind flow and which may be subleased by LTWP to different investors but has not yet been developed (LTWP 2011, 2). Five contractors have worked on different aspects of the facility: Vestas on the wind turbines, Siemens on the collection grid and substation, SECO on the permanent accommodation, Civicon on the roads, RXPE on connecting the substation to the national grid. LTWP has also upgraded $200 \mathrm{~km}$ of road between Laisamis and the project site to transport the turbines and other materials. It has taken about ten years to develop the wind farm to an operational phase. Construction began in 2014. The first turbines were erected in April 2016 and were fully installed in mid-2017. The facility has an expected lifespan of twenty-five years (LTWP 2011, 1). At the time of our research (2016) the exact nature of the wind farm's potential impact on local livelihoods remained unclear. LTWP insisted that herders would still be able to graze their animals around the turbines once construction is finished. However, there would be no access to certain areas of the concession - such as the substation and the workers' camps. Some involuntary resettlement had taken place and people were uncertain about the extent of future impacts.

\section{The Project and 'The Community'}

While the progressive environmental credentials of LTWP have not been questioned, controversial issues have emerged concerning the social impacts of the wind farm. Human rights bodies and journalists have raised concerns about lack of information, land rights, indigenous rights and the process surrounding the involuntary resettlement of a Turkana village within the project concession. Local activists formed an advocacy group called the 'Sarima Indigenous People's Land Forum' (SIPLF) in 2015 to contest the 'colonial takeover' of the land and to draw wider attention to the impacts of LTWP on local communities. ${ }^{5}$ In 2015, a case was brought to the High Court in Meru by several members of Marsabit county government, contesting the legality of the land acquisition. However, LTWP insist that they have acted in accordance with Kenyan law, have conducted consultations with local people and have invested in local socio-economic welfare (Leferink 2016). This section will explain the main issues that have emerged around the local expectations and grievances about the project.

The most contested issue is land. LTWP - like many companies making large-scale land acquisitions in Africa - has benefitted from historically weak legislation protecting 
communal land (Alden Wily 2013, 19). On 1 March 2009, LTWP acquired a 33-year lease (twice renewable) from Marsabit County Council (Voller et al. 2016, 12-15). When the lease was taken out, the land was designated as 'Trust Land' - communally owned land held in trust by local authorities. The approval of the lease from the County Council - converting the concession into private land - has meant that LTWP does not need to provide any compensation to local people for loss of land or resources. The circumstances of the lease have been a source of tension from the beginning. The minutes of an LTWP-led community consultation in July 2009 (before construction had begun) in Loiyangalani noted that land was a "significant concern" and "various people disliked the way the land had been leased to the project. Especially the lack of transparency and lack of consultation with the communities" (Carbon Africa 2009, 28).

A case was taken to the High Court in Meru contesting the legality of this lease. The complainants include the senator of Marsabit County and several Members of the County Assembly from Laisamis Constituency. They allege that the old Marsabit County Council and LTWP acted unlawfully because it did not consult with the community before issuing the lease. They also claim the lease does not follow the spirit of the new constitution of Kenya - which subsequently abolished the category of 'Trust Land' and created a new 'Community Land Act' (passed in 2016) to try to strengthen communally held land tenure. The complainants phrase these issues as infringements against indigenous identity and land rights.

The land is owned by indigenous pastoralists i.e. Rendille, El-Molo, Samburu and Turkana as an ancestral grazing land and cultural heritage since 1920. In 2008, 150,000 acres of our community land was privatised and leased to LTWP for a period of 33 years. This was done without our knowledge and with no compensation in total disregard to the Kenyan Constitution and other laws. ${ }^{6}$

LTWP has also come under scrutiny for the way it has dealt with the concept of indigenous people. The presence of indigenous people within a project footprint normally triggers certain principles and ethical standards on corporate engagement. However, there is no standard definition of 'indigenous'. In the African context, because all Africans are understood to be indigenous to Africa, definitions of indigeneity have moved away from 'first people' and towards recognition of marginalised or minority groups. The African Commission on Human and People's Rights speak of the indigenous as 'those particular groups who have been left on the margins of development and who are perceived negatively by dominating mainstream development paradigms, whose cultures and ways of life are subject to discrimination and contempt and whose very existence is under threat of extinction' (ACHPR 2005, 87). Kenya has no specific legislation on indigeneity and has not adopted the UN Declaration on the Rights of Indigenous People (UNDRIP). However, there is increasing recognition in Kenyan law of the need to protect 'minorities' and 'marginalised' people (Sing'Oei 2012). Rights and special dispensation for the 'marginalised' are enshrined in the 2010 Constitution of Kenya.

LTWP has drawn up an indigenous people's policy framework (IPPF). In it, the consortium invokes the African Commission's understanding of 'indigenous' and recognises that the Samburu, Rendille and Turkana are marginalised at a national level. However, LTWP 
reasons that in the context of northern Kenya they are 'the most dominant tribes' and are 'well adapted to the area's socio-economic and harsh environmental conditions'. Therefore, the consortium concludes that in the context of the LTWP project, pastoralists should not be considered marginalised or 'indigenous'. Instead, LTWP argues that only the El-Molo, a 'hunter-gatherer' fisher community living on the shores of Lake Turkana meet the criteria for 'indigenous'. Since the El-Molo do not live near the wind farm, this leads LTWP to ultimately conclude there are no indigenous people affected by their project (LOG Associates 2012a, 56). The Stakeholder Engagement Plan reiterates this position, and further states that because there are no indigenous people present, they have not needed to seek Free Prior Informed Consent (LTWP 2014, 7).

This is, to say the least, an atypical definition of 'indigenous'. Not only are Turkana, Rendille and Samburu widely recognised as indigenous people, they also self-identify as 'indigenous', which is a key principle of the UN definition (Martínez Cobo 1986, chapter 5). The International Working Group on Indigenous Affairs (IWGIA) has flagged the problematic logic behind LTWP's assertion that no indigenous people are affected by the project. IWGIA argues that the Samburu, Turkana and Rendille do meet the African Commission's definition of indigenous (Sena 2015, 14-15). It is hard to avoid the conclusion the LTWP has used definitional dexterity to create the appearance of adhering to ethical business standards, while avoiding the indigenous issue and the safeguards this recognition would have triggered for local people (Enns 2016, 10). Consequently, a potential channel of information and discussion for local people - including a process of free prior informed consent - has been shut down.

The resettlement of a Turkana village called Sarima has been another point of grievance. It was decided that because the village is situated close to the access road to the turbines in 'an area of high construction impact' it should be subject to an involuntary resettlement for health and safety reasons (LOG Associates 2012c, 4). It was agreed that the village would be relocated a short distance away, at the expense of the company. Because the land was Trust Land leased by LTWP, the residents of the village had no legal right to land compensation. The homes (manyattas) at Sarima are considered temporary structures according to the Kenyan land valuation act, so LTWP's consultants devised a valuation of each of the homes based on the costs of building materials, transportation and labour. They also factored in a disturbance allowance (LOG Associates 2012b, 2). The consultants conducted a census and found 114 households occupying 306 structures which they would need to move (LOG Associates 2012c, 17). Households in Sarima were given replacement manyattas and a disturbance allowance of 1,242,446 Kenyan Shillings (£8911) was distributed between the households (LOG Associates 2012b, 4). This works out as an average as 8,628 Kenyan shillings per household (£62) although reports of how much people received vary.

The new village was planned to as closely as possible reflect the original conditions of the village, but with some extra investments including pit-latrines, a classroom, a borehole and water filtration system. After the turbines have been installed, the site will be available for grazing except for the area around the HV substation and the operation village. The impression from reading the plans is that LTWP imagined the village could be easily relocated, and apart from a brief period of disruption during the construction phase, the wind farm would be developed without significant impacts: 
The construction of the wind-farm will undoubtedly be a major change to their area and to a lesser extent to the culture and lifestyle of the community. However, this will be of a temporary nature. When the plan is operational the area should revert, to a similar inactive location as should their culture and lifestyle over a period of time. The community will benefit from the project but will also be able to continue with their pastoral lifestyle during operations (LOG Associates 2012c, 18).

This assumption has been proved wrong. The population of Sarima has increased, as people have moved into the village looking for formal and informal employment opportunities with LTWP - evidence of the 'enchantment' of the project. During our research the sanitary conditions in Sarima village were of widespread concern. Even interviewees who otherwise supported the project were worried about sanitation, prostitution and excessive alcohol consumption at Sarima. A village elder complained of a breakdown of communication with the company. ${ }^{7}$ For opponents of the project, Sarima is a symbol of corporate negligence.

\section{Corporate reframing of the value of land}

One of the most striking aspects of the project is how LTWP has constructed and reframed the value of land around wind-power generation. This is partly a discursive strategy, which makes the land appear empty and investable. It is also a material reality that the turbines in the concession are set to generate large profits. A comment by the deputy manager for the liaison office of LTWP (and the most senior local person employed by the project) captures this sense of transformation:

Now there is a big project in the middle of nowhere, and this is land that never had any value, it was rocks and sand and everything, suddenly it has value now. Because the biggest wind farm in Africa is happening now. ${ }^{8}$

As Mosley and Watson have noted, the rhetoric behind current large developments in Kenya and Ethiopia repositions areas that were once seen as 'unproductive' as sites of new potential. This discourse devalues the existing uses and significance of land (Mosley and Watson 2016, 453-55). Similar strategies for rendering land investable for largescale agricultural projects have been identified worldwide ( $\mathrm{Li}$ 2014, 592-93). In Eastern Africa, this discursive construction draws on much older tropes; representing pastoralist land in particular as 'underutilised' or 'degraded' has frequently been used to implant new forms of land use (Anderson 2002; Hughes 2006).

Invoking the concession as terra nullius is an important corporate strategy ( $\mathrm{Li} 2014$ ). One early project information document describes the area as 'unpopulated'. ${ }^{9}$ An impact assessment describes it as 'a largely uninhabited, rocky, arid desert' (LTWP 2011, 6). Another notes that 'nomadic groups...roam the borders of the wind-farm concessional area' (LOG Associates 2012c, vii). The managing director has said of the site 'If you were to see images of our wind site...I would say it reminds me of pictures I used to see of the moon...there is absolutely nothing there' (Enns 2016, 10). In other ways, the planning documents made public by LTWP devalue the pastoral use and value of the land. For example, LTWP claims that 
drought, desertification and over-grazing has led to a marked decline in the carrying capacity at the project site (LTWP 2014, 18).

The idea of a frontier landscape is an important component in LTWP's corporate narrative. The consortium stresses the technical capacity needed to work at the remote site, and their innovation for executing a complex project in Marsabit County. 'Everyone thought we were a bunch of looneys' van Wageningen has explained (in Mutiga and Smith 2015), later stressing that not only is LTWP creating Africa's largest wind farm, it is doing it 'in a place that no one would have believed could ever be possible, but we have made it possible' (VESTAS 2017). This also allows the consortium to show business potential - demonstrating capacity to exploit frontier locations and harness commercial opportunities from land that was previously 'unproductive'. This transformation of land is based on technologically sophisticated solutions: converting wind into energy and capital through cutting-edge renewable energy. These ideas are encapsulated in publicity videos for the turbine engineers, VESTAS. One video begins with a sweeping shot of eastern Marsabit's rocky terrain. A voiceover rolls out: "The wind - everything you see it has shaped. It is powerful, relentless and most of all constant. And until now, no one knew what to do with it” (VESTAS 2017).

The reworking of the landscape is not only discursive. The project has brought significant physical changes to the local area. The resettled village of Sarima sits within a matrix of new camps, turbines and a substation. The road from Laisamis (on Isiolo-Moyale highway) to Sarima has been upgraded to transport the turbines. This means it is now possible to reach Marsabit, Isiolo or even Nairobi in just one day. This new value can be quantified: the wind park is projected to create 310MW, generated through 365 individual turbines each producing $850 \mathrm{KW}$. LTWP is projecting that the site will generated 1.6 billion kilowatt hours every year, which it will sell to Kenya Power at a pre-agreed tariff of 8.6 Kenyan Shillings (£0.06) per kWh (Anon 2017a). Yet these new installations and potential profits also highlight the relative poverty of the concession area. The 'village' that has been built to house the turbine engineers has 24-hour electricity, multiple Wi-Fi networks, a medical clinic, a police post and even a swimming pool. A Loiyangalani resident, employed in one of the wind-power camps told us 'it is like a heaven'. ${ }^{10}$ Meanwhile, Loiyangalani town has no mains power or running water and most residents will not be able to afford to buy the electricity that will be produced at LTWP.

\section{Historic land use and value at LTWP}

Unsurprisingly, the corporate rendering of empty and investable land belies a more complex past. In 1945, naturalist and writer Joy Adamson found rock art at Sarima, illustrating a long history of human habitation and engagement in the landscape. ${ }^{11}$ From the perspective of local pastoralist communities, the project concession area has long been a place of refuge and interaction. It is a place where different ethnic communities have historically co-existed (not always peacefully) to exploit the natural resources. The land has held diverse social, political and spiritual values. In contrast to the company's viewpoint, a member of a Loiyangalani community-based organisation, reflecting on the installation of turbines in April 2016, told us: 
When I saw the tractors and the big machines they have breaking the soil...I could really imagine this land being broken. As a pastoralist, [I thought] it was very bad. I saw the big turbines there, even though I have been to school, it was a bad picture to me because I really know the value of this land. ${ }^{12}$

Statements such as this make it clear that the land has been valued for its capacity to sustain pastoralist livelihoods. A different picture to the 'empty' concession invoked by the company can also be glimpsed in colonial archival records. These reveal how the Sarima wells have historically been a central point in the local landscape and highlight the shared use and history of the LTWP concession area.

Before colonial rule, pastoralist societies had different concepts of identity. They were highly mobile populations, with fluid ethnic boundaries. Importantly, this was predicated on a different kind of relationship with the landscape, one that was not rooted in strictly defined territorial units, but on access to resource points (Sobania 1990; Schlee 2010). This social landscape started to be reshaped during British rule, which began in the region east of Lake Turkana in 1909 (Sobania 1990, 11). Throughout the NFD, the colonial administration sought to contain people in bounded 'tribal grazing' areas. However, this was always difficult because the nature of the arid environment necessitated the movement of people and livestock in search of water between different seasons and during periods of drought. From 1919, Marsabit District Annual Reports mention the movement of destitute Turkana herders into the South Horr Valley. ${ }^{13}$ From 1931, there are regular references to Turkana manyattas around Loiyangalani. Although the administration did not condone their presence, officials recognised that people could not simply be removed because of drought conditions further south. The administration also conceded the Turkana could use the South Horr Valley as a trekking line between Sarima and the El Barta plains. ${ }^{14}$ In 1935 it was agreed by official ordinance that Turkana herders could have access to the water points in Sarima: 'the water holes along [the southern boundary of Marsabit District] are shared by the Samburu and Rendille but are rigorously prohibited to the Turkana (except those of Longerin and Sirima [sic. Sarima]). ${ }^{, 15}$ In 1945, Marsabit administrators were treating the Sarima wells as almost a de facto boundary as people from different districts were allowed to use the water point. ${ }^{16}$

There was shared use and constant movement of people in what is now the LTWP concession. Files describe the administrative complaints levelled against Rendille living near Mount Kulal for 'harbouring Turkana in their manyattas and allowing the Maralal Samburu to settle in their district. ${ }^{, 17}$ This issue was so persistent partly because it was advantageous for some Rendille herders to take in destitute Turkana.

The Rendille, who are extremely wealthy in stock, are always pleased to get poor people to herd for them for nothing and unfortunately the Turkana usually agree to live amongst the Rendille virtually as slaves. The Rendille naturally hide them as much as possible and in many cases the Turkana change their names and call themselves Rendille. ${ }^{18}$

In 1944, the District Commissioner complained that he had removed some Turkana from Moite to just south of Sarima. However, a Rendille elder had come to him to say they had no objection to the Turkana living among them, provided they had a few goats and so did not raid Rendille stock. This elder's section had recently been punished for trespassing to El Barta (an area designated by the administration as Turkana). The old man appears to have been trying to 
persuade the administration to accommodate each community's respective mobility. ${ }^{19}$ The colonial period also brought new reasons for pastoralists to migrate into Sarima and the Horr Valley from Samburu District. By the 1930s, Samburu herders with ties to across the border in Marsabit periodically came into the area to escape taxation. ${ }^{20}$ The administration was frustrated with this 'constant nuisance' especially because 'the Rendille openly condone this practice [so] it is often necessary to send inspection patrols to Kulal and to repatriate the offenders. ${ }^{21}$ This was difficult because of the fact that many of the Samburu in the district were 'so inextricably interwoven with the Rendille as to become indistinguishable'. ${ }^{22}$

As this archival snapshot from the 1930s shows, the Sarima area has historically accommodated different and overlapping communities. In the postcolonial period, northern Kenya experienced continued underdevelopment, drought and a patchwork of humanitarian interventions. Identities across the region have hardened and become more territorialised, a result of these and other historical and political processes (Watson 2010). Recently, Marsabit has been drawn closer into national politics through devolution - a process which has also transformed politics at the County level (Carrier and Kochore 2014). In contrast to the consortium's representation of the concession as 'empty', we shall explore how complex relationships between people and place have raised new dilemmas during the construction of LTWP.

\section{'All we've ever got is dust!' Securing 'benefits' from LTWP}

Before turning to the claims articulated in the project concession in 2016, we first consider what residents perceived to be at stake. When discussing LTWP during this research, it was striking that very few people objected outright to the wind farm being built. Rather, grievances focussed on the way that land acquisition, compensation and various benefits have been distributed. Almost everyone we spoke to welcomed the wind-power development in principle, but many had issues with how aspects of it were unfolding. As the Sarima Indigenous People's Land Forum (SIPLF) state in their declaration:

We are not against establishing a wind power project. We know the power of the wind in our ancestral lands, and we want it to contribute to the sustainable development of our communities, the Marsabit County and Kenya as a whole. We are determined to make this happen on the basis of our communities' ownership and leadership. ${ }^{23}$

Recognising the desire to be a part of 'development' is crucial to understanding local responses to the project and perceptions of the value of land. In this respect, the debates around LTWP reflect the findings in other recent studies of local reactions to infrastructure projects in northern Kenya. People want to be included in 'development', but tensions have surfaced around access to information, compensation and perceptions that locals are being excluded from projects and their benefits (Bremner 2013; Browne 2015, 48-62; Cormack 2016b; Elliott 2016).

The nature of these concerns make LTWP different from other cases involving the privatisation of pastoralist land in Kenya. Notably, those we spoke to were not demanding individual title for the land, but were asserting that they should be the recipients of benefits 
from the project because of a historical or ancestral connection to the land (c.f. Lesorogol 2003; Greiner 2016). The value of land was about more than the material resource itself; rather it rested significantly on what other privileges could be accessed through autochthonous claims. This situation and the resulting tensions are evident in debates and dissatisfaction surrounding employment with LTWP and the company's programme of corporate social responsibility (CSR).

The opportunities for employment at LTWP are a focus for claims and counter-claims about entitlements, with many feeling that recruitment was being unfairly allocated across different communities. For example, some Turkana people we interviewed complained that most of the jobs with G4S (a private security firm working at the site) have been given to Samburu. There was probably some truth to these accusations, as it is largely local police reservists with licensed firearms that were employed in security. As there are a greater number of Samburu with licensed firearms in the areas, it stands to reason that they make up a larger proportion of the staff employed by the security company. ${ }^{24}$ Part of the problem has been scarcity of opportunity. This reflects the technologically sophisticated 'enclave' nature of the project, which employs few locals, mainly in low status and temporary positions. In the context of sensitivities around employment, LTWP released some of its employment figures to demonstrate that it has taken an equitable approach to hiring. At its peak during the road construction, over 1,000 people from across the concession were employed on various aspects of the project. But this had dropped to 545 by February 2016 and was falling further in April 2016. ${ }^{25}$ A local committee was formed in Loiyangalani to deal with employment disputes. A religious leader who was involved with the employment committee and was sympathetic to LTWP reflected: 'the problem is that there is not enough employment for everybody. The people are always in disagreement.' 26

Tangible forms of resistance to LTWP - such as roadblocks - have appeared in the context of disagreements and perceptions of exclusion over employment. On leaving the project concession at the end of April 2016, we were stopped at a roadblock at the South HorrLaisamis-Sarima junction. A line of trucks containing equipment and staff from the LTWP facility were backed up behind thorny branches, which had been pulled across the road. We disembarked from our car to try and find out what was happening. We found that the people blocking the road were members of a family living in a kraal close to the road. They had blocked the road, they said, because they wanted to be given jobs by LTWP. They could see the turbines were being installed and feared their chances for work were diminishing. They told us they wanted to speak to the company, but no one would come to speak to them. The road block was a method of communication; the road blockers told us they had no other way to make their desires heard. A young man evocatively finished the conversation: 'all we've ever got from this road is dust [from the passing vehicles]! Well, today there will be no more dust!'27

One of LTWP's responses to grievances over limited employment opportunities has been to emphasise that it is investing in CSR programmes. The consortium argues that CSR programmes benefit everyone, not just a few individuals. LTWP invested one million euros in Laisamis constituency through its CSR foundation 'Winds of Change' between June 2015 and January 2017. It plans to invest more during the lifespan of the project as a percentage of profits from the wind-power. ${ }^{28}$ CSR is promoted by LTWP as a key 'benefit' for local people. 
Ongoing research is tracking the effects of LTWP's CSR projects on employment and local development (Kazimierczuk 2017). However, wider scholarship on CSR cautions that despite its rhetorical emphasis on 'inclusive development' and 'collaboration' with local people, these programmes often create new divisions and forms of precarity on the ground (Dolan and Rajak 2016, 18). During our period of field research, the company was reviewing its CSR programme - it needed (on its own admission) to make some changes to reflect local priorities. ${ }^{29}$ The main CSR project to have been constructed in April 2016 was accommodation for the administrative police in Loiyangalani. The Deputy County Commissioner (DCC) in Loiyangalani showed us around this facility and was pleased with the partnership. ${ }^{30}$ However, not everyone shared his enthusiasm. One interviewee in Loiyangalani, who had been present at several of the community consultation meetings explained these feelings of unease and a sense that CSR primarily serves LTWP, not the local community:

Everything is not the way they told us. That [the promise of benefits] was just a way of gaining our interest. The community never benefitted anything through the wind power. Even what they did, coming to build the police houses here, that is not a community priority. The priority here for the community is health, education or something else. But not a police post or police houses - that is a government or national government [responsibility]...The road was not built for the community, that was built because of their own business, for the transportation of their trucks to [the] Sarima site. If the materials were brought by airplane, then they would not have made the road. ${ }^{31}$

\section{Land claims at LTWP}

In the shadow of these contested benefits, local interpretations of land ownership have become strikingly more exclusive. This is partly happening because different communities feel the need to protect their own interests and secure access to new economic opportunities. Despite the complex histories of interaction between different communities, many claims around the project are crystallising an ethnic identification with place. The LTWP project did not create the idea of territorially defined identity; this process was set in motion in the colonial period and has been sustained by currents in post-colonial politics, droughts and development and relief programmes (Fratkin 2004, 39-42; Watson 2010). However, the project has dramatically raised the stakes for belonging in Sarima. The current hardening of identity is in response to the construction of LTWP. This process underlines how territorial transformations in pastoral frontiers are not solely driven by external pressures, but result from complex interactions between internal and external forces (Hoehne 2016; Korf et al 2015).

In the footprint of LTWP, ethnically differentiated claims on the concession area are invoked. We do not wish to oversimplify this process of claim-making: it is dynamic and there are intra as well as inter community contestations over the wind farm. However, three overarching claims, which are broadly associated with the three different ethnic communities are commonly invoked. Members of the Turkana community claim that they have been living in the village of Sarima for over fifty years and have gained a right to the land through use and occupation. This is not an autochthonous claim per se - interviewees acknowledged that there had been other inhabitants in the wider area before them. However, they argue that they had found no one living in the site of Sarima village when they arrived and settled. ${ }^{32}$ As one elder 
at Sarima village put it: "There are no Samburu or Rendille, it is only us that live here. When this food [LTWP] came we thought we would be the first to get a better share." ${ }^{33}$ An additional claim is that they have buried their relatives in the land. Particularly, they point to the graves of a family of diviners called 'Longori' - very revered and respected family. Following insecurity at Sarima in 2015, the current diviner has now left and has settled near Moite. He is said to have made several prophecies - including that the construction of LTWP will cause a volcanic eruption and that the project will result in a war with the government. ${ }^{34}$

A second claim is associated with Samburu history; it asserts that the project concession is within Samburu ancestral land. This claim is centred on the Ongeli clan, who assert that their forebears had historic links to Sarima. Their clan myth narrates that the ancestors of Ongeli used to live by the 'Mugur e Sarima', a seasonal water pool in the centre of Sarima. The story goes that the ancestors once had a small quantity of honey, which was not enough for them to share among themselves. They decided to empty the honey container into the water of the Mugur e Sarima so that each of them could have a taste of the honey. The honey made the water sweet and most people drank until they were satisfied. However, some people could not stop drinking the sweet water: they drank until their stomachs burst open and they died. They were later buried near the Mugur e Sarima. For this reason, the Samburu claim that Sarima bears historical importance to all the Samburu people and for the Ongeli clan in particular. ${ }^{35}$ This account is now routinely invoked in discussions about Sarima and LTWP.

Another claim to land is based around Rendille culture and identity. Rendille interviewees asserted an ancestral claim to Sarima. Elders described how they abandoned the area after Kenyan independence, mainly because of the insecurity that resulted from the influx of the Turkana who increasingly raided them. ${ }^{36}$ Rendille interviewees also invoked the Ongeli ancestor story - this clan is found among both Samburu and Rendille (a further indication of how imbricated their relationships are). Additionally, Sarima was once an important site where they used to conduct a Rendille age set ceremony called Galgulame. This ceremony is of great cultural and spiritual significance to the Rendille community. It symbolises the exchange of age-sets which is conducted every fourteen years. An important reason Sarima was chosen for this ceremony is that it is near a permanent source of water (Lake Turkana). Part of the ritual activity requires that newly installed age-sets immerse themselves in water, cleansing themselves in the process. The permanent water symbolises the continuity and prosperity of the age-set (Spencer 2012, 46-48). The last Galgulame ceremony conducted at Sarima was in 1953. The most recent Galgulame ceremony was conducted within Marsabit National Park, on a small crater lake called Lake Paradise.

A key feature of these different claims is how they invoke historical and cultural ties to land in the concession. Graves, the Galgulame ceremony, stories about the Ongeli clan and mugur e Sarima are 'tools of territoriality' that are being strategically deployed to make a claim on the wind-farm (Shipton 2009, 96). As the wind turbines have risen, these tools have formed the basis of claims to rights in the land and 'benefits' of LTWP. A clear indication of how the project is reanimating relationships to place is the revival of Sarima's ritual significance. One of the grievances listed by the complainants of the court case is the importance of Sarima for the Rendille Galgulame ceremony. ${ }^{37}$ Elites involved in the court case have stressed the cultural importance of Sarima for the Rendille, even though Galgulame has not taken place at Sarima since the 1950s. 
There are also signs of more alarming consequences of these hardening positions. There is a history of local conflict and Sarima plains have been used as a route for livestock rustlers. LTWP has invested in security and claim that they have improved security in the concession (Leferink 2016, 2). However, opponents of the project suggest the development has increased conflict in the area. ${ }^{38}$ They point to a series of conflicts that took place in the project concession in April and May 2015. Unusually, a Rendille livestock camp was attacked and three children were killed. There is a history of conflict between the Samburu and Turkana, while the Rendille have had cordial relationships with the Turkana and Samburu in the in the project concession for decades, so this has been interpreted as a sudden change in conflict dynamics. Among other violent incidents, on 4 May 2015, Sarima village was attacked and three people were killed (more were injured and displaced) (Abdi 2015). As one resident of Sarima told us, "the Samburu want to fight us here, so that that we move from here and the project belongs to them...but they don't even have their grave markers here, so they have never lived here”. ${ }^{39}$

\section{Conclusion}

There are two strikingly different narratives surrounding the LTWP investment. One, advanced by the consortium and its supporters, asserts that the project is bringing development and stability to a long-marginalised area, and is supported by local people, who welcome the corporate transformation of the region and the opportunities it will bring (e.g. Cookson et al. 2017; VESTAS 2017). Another, advanced by local and international critics of the project, holds that LTWP has obtained land without informed consent and has failed in its duty of care to resettled and indigenous populations. In this view, the project has exploited local people, who will be left out of the profits from this development (e.g. Voller et al. 2016).

It has not been our intention in this article to argue for either side. Rather, it has been to explore the point on which both narratives converge: the project has radically transformed the value and significance of land. Two important insights for understanding the changing value of land emerge from the LTWP case study. The new economic significance of the land interacts with historic and cultural values held by local pastoralist populations. Rather than displace these 'older' attachments, the project has reinvigorated existing connections. Historical and cultural attachments to land have become a basis for accessing 'benefits' from LTWP. This situation has emboldened notions of territoriality, as people have felt compelled to make increasingly exclusive claims, in order to protect their own interests and to position themselves as the legitimate beneficiaries of the project. This highlights the second major insight we have explored: that the value of land is about more than its physical substance and use. It rests significantly on the other resources and privileges that could be accessed through claims to indigenous land rights, such as employment opportunities, corporate social investments and a generalised aspiration for 'development'. Therefore, how land is assembled as a resource can shift and this is crucial to understanding how its value is both constituted and contested.

A final point to reiterate is that these processes are happening in tandem with the emergence of new forms of exclusion as LTWP has become the gatekeeper to new resources and positions of power. These findings have implications beyond this case study. Major infrastructure projects that are constructed in marginalised regions of the horn of Africa do not 
enter an empty space; they transform and sit uneasily beside older values, creating new forms of contestation and inequality.

\section{Acknowledgements}

We wish to thank everyone who spoke to us in Marsabit County. We hope that this article will positively contribute towards understanding processes currently underway across the region. Although every effort has been made to verify the information discussed here, we take responsibility for any errors of fact and interpretation. Boru Hussein Boru (and 'KAP') provided important logistical support on the journey to Loiyangalani and shared some insightful first impressions of the concession area. We further thank Cherry Leonardi, Adrian Browne and two anonymous reviewers for their thoughtful comments on earlier versions of this article.

\section{Notes}

\footnotetext{
${ }^{1}$ See the Vision2030 website for list of 'flagship' projects http://www.vision2030.go.ke/projects/?pj=2 (accessed 15.04.2017).
}

${ }^{2}$ A businessman from Marsabit, driving through the Lake Turkana Wind Power site. Fieldnotes 27.04.2016.

${ }^{3}$ Currency conversions given in this article are based on the conversion rate between Kenyan Shillings and UK Pounds in December 2017

${ }^{4} \mathrm{~A}$ forthcoming $\mathrm{PhD}$ thesis is exploring the local effects of LTWP in ethnographic perspective. See (Drew 2018)

${ }^{5}$ SIPLF 'Background'. A copy of this document is on file with the authors.

6 'Community Grievances Against Lake Turkana Wind Power' p.1 A copy of this document is on file with the authors.

${ }^{7}$ Mars_intrv015 Elder, Sarima 27.04.2016.

${ }^{8}$ Mars_intrv016 LTWP Senior Liaison officer, Sarima, 27.04.2016.

9 'Insight into the Turkana Windpark in Marsabit District, Kenya', p 6 November 2004. Produced by 'Turkana Wind Power' (an older name of Lake Turkana Wind Power). A copy of this document is on file with the authors.

${ }^{10}$ Mars_intrv006 LTWP employee, Loiyangalani 23.04.2016.

${ }^{11}$ Kenya National Archives (KNA) PC/NFD/1/2/1 Marsabit District Annual Report, 1945, p.26.

${ }^{12}$ Mars_intrv005 Community Based Organisation leader, Loiyangalani 23.04.2016.

${ }^{13}$ KNA PC/NFD/1/2/1 Marsabit District Annual Report, 1919, p.1.

${ }^{14}$ KNA PC/NFD/1/2/2 Marsabit District Annual Report, 1931, p.4.

${ }^{15}$ KNA PC/NFD/2/2/2 Marsabit District Handing Over Report, 1935, p.3.

${ }^{16}$ KNA PC/NFD/2/2/3 Marsabit District Handing Over Report, 1945, p.8.

${ }^{17}$ KNA PC/NFD/1/2/2 Marsabit District Annual Report, 1936, p.12.

${ }^{18}$ KNA PC/NFD/1/2/3 Marsabit District Annual Report. 1937, p.8.

${ }^{19}$ KNA PC/NFD/1/2/4 Marsabit District Annual Report 1944, p.9.

${ }^{20}$ KNA PC/NFD/2/2/2 Marsabit District Handing Over Report, 1937.

${ }^{21}$ KNA PC/NFD/2/2/2 Marsabit District Handing Over Report, 1940, p.31.

${ }^{22}$ KNA PC/NFD/2/2/2 Marsabit District Handing Over Report, 1937, p.4.

${ }^{23}$ SIPLF 'Background'. A copy of this document is on file with the authors.

${ }^{24}$ Mars_intrv016 LTWP Senior Liaison officer, Sarima, 27.04.2016.

${ }^{25}$ Mars_intrv016 LTWP Senior Liaison officer, Sarima, 27.04.2016. For employment figures in February 2016 see Leferink (2016, 2). 
${ }^{26}$ Mars_intrv013 Religious leader, Loiyangalani 26.04.2016.

${ }^{27}$ Mars_intrv021 Young man at a road block, South Horr-Laisamis-Sarima junction 29.04.2016.

${ }^{28}$ LTWP Winds of Change Foundation Newsletter January 2017. A copy of this document is on file with the authors.

${ }^{29}$ Mars_intrv016 LTWP Senior Liaison officer, Sarima, 27.04.2016.

${ }^{30}$ Mars_intrv011 Local government official, Loiyangalani, 26.04.2016.

${ }^{31}$ Mars_intrv012 Businessman, Loiyangalani 26.04.2016.

35 'Community Grievances Against Lake Turkana Wind Power’ p.4; Mars_intrv028 Nairobi 07.04.2016.29/05/2018 14:17:00

${ }^{36}$ Community Grievances against LTWP, p.10.

${ }^{37}$ Mars_intrv015 Elder, Sarima 27.04.2016.

\section{References}

Abdi, Ali. 2015. 'Children Killed in Bandit Attack in Loiyangalani'. The Standard, 7 May 2015. https://www.standardmedia.co.ke/article/2000161323/children-killed-in-banditattack-at-loiyangalani.

ACHPR. 2005. 'Report of the African Commission's Working Group on Indigenous Populations/Communities'. Piscataway, NJ: Transaction Publishers/ACHPR and IWIGIA.

Alden Wily, Liz. 2013. 'Enclosure Revisited: Putting the Global Land Rush in Historical Perspective'. In Handbook of Land and Water Grabs in Africa: Foriegn Direct Investment and Food and Water Security, edited by Tony Allan, Martin Keulertz, Suvi Sojamo, and Jeroen Warner. Abingdon: Routledge.

Anderson, David. 2002. Eroding the Commons: The Politics of Ecology in Baringo, Kenya 1890-1968. Oxford: James Currey.

Anon. 2014. 'Deal Paves Way for Lake Turkana Power Plant'. Daily Nation, 8 December 2014. http://www.nation.co.ke/business/Deal-paves-way-for-setting-up-of-windpower-farm-farm/996-2549118-odvtfi/index.html.

- - . 2017a. 'Turkana Wind Power Project Yields 102MW'. REVE: Wind Energy and Electric Vehicle Review, 28 February 2017. http://www.evwind.es/2017/02/28/turkanawind-power-project-yields-102-mw/58950.

- - . 2017b. 'Kenya: Gov Takes over Lake Turkana Transmission Line Paymemt'. ESI Africa, 30 March 2017. https://www.esi-africa.com/news/kenyan-gov-gets-involved-inpower-transmission-line/.

Berry, Sarah. 2007. 'Marginal Gains, Market Values and History'. African Studies Review 50 (2): $57-70$.

Bremner, Lindsay. 2013. 'Towards a Minor Global Architecture at Lamu, Kenya'. Social Dynamics: A Journal of African Studies 39 (3): 397-413.

Browne, Adrian. 2015. 'LAPSSET: The History and Politics of an Eastern African Megaproject'. London: The Rift Valley Institute.

Buffavand, Lucie. 2016. "The Land Does Not like Them": Contesting Dispossession in Cosmological Terms in Mela, South-West Ethiopia'. Journal of Eastern African Studies 10 (3): 476-93.

Carbon Africa. 2009. 'Gold Standard Local Stakeholder Consultation Report'. Carbon Africa: Nairobi. 
Carrier, Neil, and Hassan Kochore. 2014. 'Navigating Ethnicity and Electoral Politics in Northern Kenya: The Case of the 2013 Election'. Journal of Eastern African Studies 8 (1): 135-52.

Cookson, Pamela, Jessica Kuna, and Emily Golla. 2017. 'Benefits of Low Emission Development Strategies: The Case of Kenya's Lake Turkana Wind Power Project'. Low Emission Development Strategies Global Partnership.

Cormack, Zoe. 2016a. 'Borders Are Galaxies: Interpreting Contestations over Local Administrative Boundaries in South Sudan'. Africa: Journal of the International African Institute 86 (3): 504-27.

- - . 2016b. 'The Promotion of Pastoralist Heritage and Alternative "Visions" for the Future of Northern Kenya'. Journal of Eastern African Studies 10 (3): 548-67.

Cusick, Daniel. 2016. 'Why Google Cares About Wind Power in Africa'. ClimateWire from Environment \& Energy Publishing, 11 October 2016. https://www.eenews.net/climatewire/2016/10/11/stories/1060044084.

Dodd, Jan. 2012. 'World Bank Withdraws Support for Lake Turkana Wind Power Project'. Wind Power Monthly, 22 October 2012. http://www.windpowermonthly.com/article/1156128/world-bank-withdrawssupport-lake-turkana-wind-power-project.

Dolan, Catherine, and Dinah Rajak. 2016. 'Introduction: Towards an Anthropology of Corporate Social Responsibility'. In The Anthropology of Corporate Social Responsibility. Oxford: Bergahn Books.

Drew, James. 2018. 'Pastoralism in the Shadow of a Windfarm: An Ethnography of People, Places and Belonging in Northern Kenya'. PhD., Brighton: University of Sussex.

Elliott, Hannah. 2016. 'Planning, Property and Plots at the Gateway to Kenya's "New Frontier"'. Journal of Eastern African Studies 10 (3): 511-29.

Elmi, Mohamed, and Izzy Birch. 2013. 'Creating Policy Space for Pastoralism in Kenya'. Future Agricultures Consortium Working Paper 068.

Enns, Charis. 2016. 'The Master's Tools: Voluntary Social and Environmental Standards and the Politics of Legitization in East Africa's Extractive Sector'. The Hague: ISS.

Enns, Charis, and Brock Bersaglio. 2015. 'Enclave Oil Development and the Rearticulation of Citizenship in Turkana, Kenya: Exploring “Crude Citizenship"'. Geoforum 67: 78-88.

- - - 2016. 'Pastoralism in the Time of Oil: Youth Perserpectives on the Oil Industry and the Future of Pastoralism in Turkana, Kenya'. The Extractive Industries and Society 3 (1): 160-70.

Ferguson, James. 2005. 'Seeing Like an Oil Company: Space, Security, and Global Capital in Neoliberal Africa'. American Anthropologist 107 (3): 377-82.

Fontein, Joost. 2016. Remaking Mutirikwi: Landscape, Water and Belonging in Southern Zimbabwe. Oxford: James Currey.

Fratkin, Elliot. 2004. Ariaal Pastoralists of Kenya: Studying Pastoralism, Drought, and Development in Africa's Arid Lands. Boston: Pearson Education.

- - - 2014. 'Ethiopia's Pastoralist Policies: Development, Displacements and Resettlement'. Nomadic Peoples 18 (1): 94-114.

Galvin, Kathleen. 2009. 'Transitions: Pastoralists Living with Change'. Annual Review of Anthropology 38: 185-98.

GoK. 2012. Vision 2030 Development Strategy for Northern Kenya and Other Arid Lands. Nairobi: Government of Kenya. 
Greiner, Clemens. 2016. 'Land-Use Change, Territorial Restructuring, and the Economies of Anticipation in Dryland Kenya'. Journal of Eastern African Studies 10 (3).

Hoehne, Markus Virgil. 2016. 'The Rupture of Territoriality and the Diminishing Relevance of Cross Cutting Ties in Somalia after 1991'. Development and Change 47 (6): 13791411.

Hogg, Richard. 1987. 'Development in Kenya: Drought, Desertification and Food Scarcity'. African Affairs 86 (342): 47-58.

Howe, Cymene. 2011. 'Logics of the Wind: Development Desires over Oaxaca'. Anthropology News, May, 8.

Hughes, Lotte. 2006. Moving the Maasai: A Colonial Misadventure. Basingstoke: Palgrave Macmillan.

Human Rights Watch. 2012. "“What Will Happen If Hunger Comes?”: Abuses against the Indigenous Peoples of Ethiopia's Lower Omo Valley'.

Johannes, Eliza M, Leo C Zulu, and Ezekiel Kalipeni. 2015. 'Oil Discovery in Turkana County, Kenya: A Source of Conflict or Development?' African Geographical Review 43 (2): 142-64.

Kamau, Macharia. 2017. 'How Power Line Meant to Bring down Cost of Electricity Will Push up Bills'. The Standard, 22 October 2017. https://www.standardmedia.co.ke/business/article/2001258005/kenya-pays-sh5-7billion-penalty-for-turkana-wind-power-line-delay.

Kazimierczuk, Agnieszka. 2017. 'Research Update: Taking off against the Wind: Impact of the Wind Mega Project on Inclusive Development in Kenya'. Netherlands: INCLUDE: Knowledge Platform on Inclusive Development.

http://includeplatform.net/research-update-taking-off-wind-impact-wind-megaproject-inclusive-development-kenya/.

Kochore, Hassan H. 2016. 'The Road to Kenya? Vision, Expectations and Anxieties around New Infrastructure Development in Northern Kenya'. Journal of Eastern African Studies 10 (3): 494-510.

Korf, B, T Hagmann, and R Emmenegger. 2015. 'Re-Spacing African Drylands:

Territorialization, Sedentarization and Indigenous Commodification in the Ethiopian Pastoral Frontier'. The Journal of Peasant Studies 42 (5): 881-901.

Larkin, Brian. 2013. 'The Politics and Poetics of Infrastructure'. Annual Review of Anthropology 42: 327-43.

Leferink, Philip. 2016. 'Statement by Lake Turkana Wind Power Limited on Concerns Raised in the IWIGIA Report Titled 'Renewable Energy Projects and the Rights of Marginalised/Indigenous Communities in Kenya'. Nairobi: Lake Turkana Wind Power.

Lesorogol, Carolyn. 2003. 'Transforming Institutions among Pastoralists: Inequality and Land Privatisation'. American Anthropologist 105 (3): 531-5541.

Li, Tania Murray. 2014. 'What Is Land? Assembling a Resource for Global Investment'. Transactions of the Institute of British Geographers 39: 589-602.

LOG Associates. 2012a. 'Lake Turkana Wind Project: Indigenous People's Policy Framework'. Nairobi: Lake Turkana Wind Power.

- - - 2012b. 'Valuation Report for Sirima Village. Final Report'. Nairobi: Lake Turkana Wind Power.

- - . 2012c. 'Abbreviated Resettlement Action Plan: Lake Turkana Wind Power. Relocation of Sirima Encampment, Marsabit District.' Nairobi: Lake Turkana Wind Power. 
LTWP. 2011. 'Updated Environmental and Social Impact Assessment Summary'. Nairobi: Lake Turkana Wind Power.

- - - 2014. 'Stakeholder Engagement Plan. Revision 7'. Nairobi: Lake Turkana Wind Power.

Martínez Cobo, José. 1986. 'Study of the Problem of Discrimination Against Indigenous Populations. UN Doc. E/CN.4/Sub.2/1986/7'. New York: United Nations. https://www.un.org/development/desa/indigenouspeoples/publications/martinezcobo-study.html.

Menkhaus, Ken. 2014. 'Conflict Assessment/2014 Northern Kenya and Somaliland'. Nairobi: Danish Demining Group.

Mkutu Agade, Kennedy. 2014. "'Ungoverned Space" and the Oil Find in Turkana, Kenya'. The Round Table 103 (5): 497-515.

- - - 2015. 'Changes and Challenges of the Kenya Police Reserve: The Case of Turkana County'. African Studies Review 58 (1): 199-222.

Mosley, Jason, and Elizabeth Watson. 2016. 'Frontier Transformations: Development Visions, Spaces and Processes in Northern Kenya and Southern Ethiopia'. Journal of Eastern African Studies 10 (3): 452-75.

Muthoka, Johnson. 2011. 'Suswa-Loyangalani Transmission Line Disclosure Document'. Nairobi: KETRACO.

Mutiga, Murithi, and David Smith. 2015. 'Africa's Largest Windfarm Set to Connect Remote Kenya to the Grid'. The Guardian, 9 October 2015. https://www.theguardian.com/environment/2015/oct/09/africas-largest-windfarmset-to-connect-remote-kenya-to-the-grid.

Mwangi, Oscar Gakuo. 2006. "Kenya: Conflict in the "Badlands": The Turbi Massacre in Marsabit District'. Review of African Political Economy 33 (107): 81-91.

Opiyo, Francis, Oliver Wasonga, Moses Nyangito, Janpeter Schilling, and Richard Munang. 2015. 'Drought Adaptation and Coping Strategies Among the Turkana Pastoralists of Northern Kenya'. International Journal of Disaster Risk Science 6 (3): 295-309.

Rottmann, Felix. 2017. 'Winds of Change Newsletter'. Nairobi: Lake Turkana Wind Power. https://Itwp.co.ke/newsite/wp-content/uploads/20170619-WoC-Newsletter-June2017.pdf.

Sack, Robert David. 1986. Human Territoriality: Its Theory and History. Cambridge: Cambridge University Press.

Schlee, Gunther. 2010. 'Territorialising Ethnicity: The Political Ecology of Pastoralism in Northern Kenya and Southern Ethiopia'. Halle: Max-Planck Institute.

Scott, James. 1998. Seeing Like a State: How Certain Schemes to Improve the Human Condition Have Failed. London: Yale University Press.

Sena, Kanyinke. 2015. 'Renewable Energy Projects and the Rights of Marginalised/Indigenous Communities in Kenya'. Copenhagen: International Work Group for Indigenous Affairs (IGWIA).

Shipton, Parker. 2009. Mortgaging the Ancestors: Ideologies of Attachment in Africa. London: Yale University Press.

Sing'Oei, Korir. 2012. 'Kenya at 50: Unrealized Rights of Minorities and Indigenous Peoples'. London: Minority Rights Group.

Sobania, N.W. 1990. 'Social Relationships as an Aspect of Property Rights: Northern Kenya in the Pre-Colonial and Colonial Period'. In Property, Poverty and People: Changing 
Rights in Property and Problems of Pastoral Development, edited by P.T.W Baxter and Richard Hogg. Manchester: University of Manchester.

Spencer, Paul. 2012. Nomads in Alliance: Symbiosis and Growth among the Rendille and Samburu of Kenya. Oxford: Oxford University Press.

VESTAS. 2017. Lake Turkana: The Windiest Place on Earth.

https://www.youtube.com/watch?v=pYsaQfIll8U\&t=392s.

Voller, Louise, Anders Brønd Christense, Geoffrey Kamadi, and Han van der Wiel. 2016. 'A People in the Way of Progress'. Denmark: Danwatch.

Watson, Elizabeth. 2010. "A Hardening of Lines": Landscape, Religion and Identity in Northern Kenya'. Journal of Eastern African Studies 4 (2): 201-20.

${ }^{32}$ Mars_intrv004 Former LTWP community liaison officer, Loiyangalani 23.04.2016.

${ }^{33}$ Mars_intrv015 Community leader, Sarima 27.04.2016.

${ }^{34}$ We heard this from several people and tried to visit the diviner to confirm the details of his prophecy, but we had to turn back because his homestead was too far from the road for us to access.

${ }^{35}$ Mars_intrv019 Elder, South Horr, 28.04.2016.

${ }^{36}$ Mars_intrv023 Elder, Hula Hula, Marsabit 01.05.2016. 